\title{
Differential inhibition of endothelial cell proliferation and migration by urokinase subdomains: amino-terminal fragment and kringle domain
}

\author{
Kwang Sei Kim ${ }^{1 *}$, Yong-Kil Hong ${ }^{1 *}$ \\ Yoon Lee', Joo-Young Shin' \\ Soo-lk Chang ${ }^{2}$, Soo II Chung $^{3}$ and \\ Young Ae Joe ${ }^{1,4}$ \\ 'Cancer Research Institute \\ Catholic Research Insftute of Medicial Sciences \\ The Catholic University of Korea \\ Seoul 137-701, Korea \\ ${ }^{2}$ Department of Biochemistry \\ Colege of Natural Science \\ Chungbuk National University \\ Cheongju 361-763, Korea \\ ${ }^{3}$ Department of Oral Pathology \\ Colege of Dentistry \\ Kangnung National University \\ Gangneung, Gangwon-do 210-702, Korea \\ ${ }^{4}$ Corresponding author: Tel, 82-2-590-2404; \\ Fax, 82-2-532-0575; E-mail, youngjoe@catholic.ac.kr \\ 'These authors contributed equaly to this work.
}

Accepted 12 December 2003

Abbreviations: bFGF, basic fibroblast growth factor; CAM, chorioallantoic membrane; HUVE, human umbilical vein endothelial; scu-PA, single-chain UPA; U-ATF, amino-terminal fragment of uPA; UK1; kringle domain of UPA; UPA, urokinase plasminogen activator; UPAR, UPA receptor

\section{Abstract}

The serine protease urokinase-type plasminogen activator (UPA) is implicated in pericellular prote. olysis in a variety of physiological and pathological processes including angiogenesis and tumor metastasis. The kringle domain of UPA (UK1) has proven to be an anti-angiogenic molecule with unknown mechanism and amino terminal fragment of uPA (U-ATF) with additional growth factor-like do$m$ ain can be used for blocking interaction of UPA and UPA receptor. Here, we compared anti-angiogenic activities of these two molecules in vitro and in vivo. The recombinant U-ATF from $E$. coli and refolded in vitro was found to bind to UPAR with high affinity, whereas $E$. coli-derived UK1 showed no binding by Biacore analysis. In contrast to UK1 having potent inhibitory effect, U-ATF exhibited low inhibitory effect on bovine capillary endothelial cell growth $\left(E D_{50}>320 \mathrm{nM}\right)$. Furthermore, U-A TF inhibition of VEGF-induced migration of human umbilical vein endothelial cell was far less sen. sitive $\left(I C_{50}=600 \mathrm{nM}\right)$ than those observed with UK1, and angiogenesis inhibition was marginal in chorioallantoic membrane. These results suggest that kringle domain alone is sufficient for potent antiangiogenic activity and additional growth factor-like domain diverts this molecule in undergoing different mechanism such as inhibition of UPA/UPAR interaction rather than undergoing distinct antiangiogenic mechanism driven by kringle domain.

Keywords: angiogenesis inhibitors; angiostatic proteins; cell migration inhibition; endothelial cells; urokinase-type plasminogen activator

\section{Introduction}

Urokinase-type plasmingen activator (UPA) and its receptor are important components of cell surface proteolysis used by tumor cells and capillary endothelial cells for basement membrane invasion and implicated in the progression, metastasis, and angiogenesis of numerous tumors (de Vries et $a_{n}, 1996$; Andreasen et al., 1997; Reuning et al., 1998). uPA is secreted from cells as a single-chain proenzyme that is cleaved by plasmin into its two-chain active form (Petersen et al., 1988). Both the single and two-chain forms can bind to U-PA receptor (UPAR). The two chain form consists of A (aa 158) and B (aa 159-411) polypeptide chains linked by disulfide bonds. Single-chain uPA (scu-PA) is a multidomain protein composed of a carboxylterminal protease domain, termed low molecular weight scu-PA (LMW-scu-PA) and an amino-terminal fragment (U-ATF), which can be further subdivided into a growth factor-like domain (aa 4-43) and a kringle domain (aa 45-135) (Figure $1 \mathrm{~A})$. The general feature of kringle structure is composed of $78-80$ amino acids inter-connected by a triple disulfide-linked loop.

The high level expression of UPA and UPA receptor (UPAR) are correlated with a poor prognosis in a num- 
ber of malignancies, including breast, gastric, brain and lung cancer (Sappino et al., 1987; Yamamoto et al., 1994b; Foekens et al., 1995; Park et al., 1997) and is often localized to the leading, invasive edge of a tumor (Estreicher et al., 1990; Yamamoto et al., 1994a). Blockage of the interaction of UPA and its receptor has resulted in inhibition of the migration and spreading of malignant tumor cells (Crowley et al., 1993; Mohanam et al., 2002).

During angiogenesis, endothelial cells need to divide, migrate, invade into the extracellular matrix, and form capillary structures from preexisting blood vessels. The process of cell invasion requires the production of a key active cell surface protease, uPA. Treatment of capillary endothelial cells with angiogenic factors such as basic fibroblast growth factor (bFGF) and VEGF causes up-regulation of uPA (Saksela et al., 1987) and UPAR (Mignatti et al., 1991; Mandriota et al., 1995). Interference with the activities of the UPA system has been demonstrated in some cases inhibition of angiogenesis in vitro (Yasunaga et al., 1989; Lu et al., 1996; Min et al., 1996; Fibbi et al., 1998), and in vivo (Min et al., 1996; Li et al., 1998).

ATF-based uPAR antagonists are known to have anti-angiogenic function mainly by blocking uPA/uPAR interaction (Lu et al., 1996; Li et al., 1998). Recently, the recombinant kringle domain of urokinase (UK1) has been shown to present anti-angiogenic activity in vitro and in vivo by unknown mechanism (Kim et al., 2003b). Since U-ATF contains potential two inhibitory domains; a growth factor-like domain where uPAR binding domain is located and a kringle domain, it will be an intriguing question whether U-ATF acts like UK1 on endothelial cells or whether U-ATF elicits more potent anti-angiogenic activity than UK1 due to one additional functional epitope. Therefore, in this study, we compared the anti-angiogenic activities of these two molecules.

\section{Materials and Methods}

\section{Materials}

Recombinant scu-PA expressed in Chinese hamster ovary cells was obtained from Mogam Biotechnology Research Institute (Kyungki-do, Korea). The reagents used for cell culture, M199, DMEM, FBS and trypsin solution were purchased from Life Technologies (Gaithersbug, MD). VEGF and bFGF were purchased from R\&D system (Minneapolis, MN).

\section{Cell culture}

Human umbilical vein endothelial (HUVE) cell was isolated from fresh cords by an adaptation of the method described by Jaffe et al. (1973), and main- tained in M199 medium containing $20 \%$ FBS, 30 $\mu \mathrm{g} / \mathrm{ml}$ endothelial cell growth supplements (Sigma), 90 $\mu \mathrm{g} / \mathrm{ml}$ heparin, $25 \mathrm{mM}$ Hepes, $2.2 \mathrm{~g} / \mathrm{L}$ sodium bicarbonate, $2 \mathrm{mM}$ L-glutamine and penicillin/ streptomycin antibiotics. Cells at passage 3,4 or 5 were used for the experiments. Bovine capillary endothelial (BCE) cell was obtained from Dr. TH Lee (Lee et al., 1998), and maintained in DMEM containing $10 \%$ FBS and $1 \%$ penicillin/streptomycin antibiotic, and $3 \mathrm{ng} / \mathrm{ml}$ bFGF. Cultures were kept at $37^{\circ} \mathrm{C}$ in a humidified atmosphere of $10 \% \mathrm{CO}_{2}$ in air for BCE cells and $5 \%$ $\mathrm{CO}_{2}$ in air for HUVE cells.

\section{Expression and purification of U-ATF}

A transformant expressing U-ATF was obtained by transformation of $E$. coli BL21 (DE3) with pET-21d/ATF which was constructed previously (Kim et al., 2003b). Expression and purification of U-ATF were performed as previously described for UK1 production. A single colony of the transformant was grown in 2.5 liter of LB medium containing $100 \mathrm{mg} / \mathrm{ml}$ of ampicillin at $37^{\circ} \mathrm{C}$ to a $A_{600}$ of about $0.6-0.8$. To induce the production of recombinant protein, isopropyl thio- $\beta$-o-galactopyranoside (IPTG) was added to a final concentration of $1.0 \mathrm{mM}$. Cells were incubated for an additional 3 $\mathrm{h}$ at $37^{\circ} \mathrm{C}$ and finally harvested by centrifugation for $15 \mathrm{~min}(8,000 \mathrm{~g})$. The cell paste was stored at $-70^{\circ} \mathrm{C}$. The cell pellet was thawed, suspended in a lysis buffer [ $20 \mathrm{mM}$ Tris- $\mathrm{Cl}$, pH $8.0,50 \mathrm{mM} \mathrm{NaCl}, 1 \mathrm{mM}$ $\mathrm{MgCl}_{2}, 0.1 \mathrm{mM} \mathrm{CaCl}$, RNase A (20 mg/ml), DNase I $50 \mu \mathrm{g} / \mathrm{ml}$, and subjected to sonication for $15 \mathrm{~min}$. The soluble and insoluble fractions were separated by centrifugation for $30 \mathrm{~min}$ at $20,000 \mathrm{~g}$. The insoluble fraction was dissolved in a buffer $\mathrm{C}(20 \mathrm{mM}$ Tris- $\mathrm{Cl}$, $\mathrm{pH} 7.9,0.5 \mathrm{M} \mathrm{NaCl}, 8 \mathrm{M}$ Urea) and diluted to $6 \mathrm{M}$ urea. After centrifugation, the supernatant was applied to a ProBond ${ }^{\mathrm{TM}}$ resin His-tag affinity column equilibrated with buffer D $(20 \mathrm{mM}$ Tris- $\mathrm{Cl}, \mathrm{pH} 7.9,0.5 \mathrm{M}$ $\mathrm{NaCl}, 6 \mathrm{M}$ urea). The column was washed with 20 $\mu \mathrm{M}$ imidazole-containing buffer $\mathrm{D}$, and protein was eluted with $1 \mathrm{M}$ imidazole-containing buffer $\mathrm{D}$. After confirming by SDS-PAGE, the fractions containing the desired protein were combined and stepwise diluted with buffer $\mathrm{F}(0.1 \mathrm{M}$ Tris- $\mathrm{Cl}, 0.15 \mathrm{M} \mathrm{NaCl}, \mathrm{pH} 8.0)$. While diluted, the solution was added with reduced $(1 \mathrm{mM})$ and oxidized $(0.1 \mathrm{mM})$ glutathione and incubated at room temperature overnight. The solution was concentrated by ultrafiltration and dialyzed against sodium acetate buffer $(\mathrm{pH} \mathrm{5.5)}$ and distilled water. The dialyzed solution was lyophilized, dissolved in buffer $\mathrm{G}(20 \mathrm{mM}$ sodium phosphate, $150 \mathrm{mM} \mathrm{NaCl}$, $\mathrm{pH}$ 6.8), and applied to a Bio-prep SE 100/17 column equilibrated with the same buffer for the final purification. The endotoxin level of the purified proteins was less than $0.3 \mathrm{U} / \mathrm{mg}$ protein. 


\section{Binding assay by Biacore biosensor}

Binding assays of scu-PA, U-ATF, and UK1 was performed by real time interaction analysis using a Biacore 2000 apparatus (Biacore AB, Uppsala, Sweden). All experiments were performed at $20^{\circ} \mathrm{C}$ using PBS buffer containing $0.005 \%$ (v/v) surfactant P20 (Biacore $A B$, running buffer). The recombinant uPAR $(20 \mu \mathrm{g} / \mathrm{ml}$ in $10 \mathrm{mM}$ sodium acetate buffer, $\mathrm{pH} 5.0$ ) purchased from R\&D system (870-UK/CF) was immobilized on a CM-5 type sensor chip using the reagents and procedures supplied with the Amine Coupling Kit (Biacore AB). The samples of scu-PA, U-ATF, and UK1 were diluted in the running buffer before injection. For general binding assay, each sample was injected over the human UPAR at a flow rate of $10 \mu \mathrm{\mu} / \mathrm{min}$. The kinetic of binding were measured at a buffer flow of $30 \mu / / m i n$, including an injection phase of $3 \mathrm{~min}$ followed by dissociation for $5 \mathrm{~min}$. Sensor chips were regenerated at the end of each run by injection of 0.05 $\mathrm{M}$ acetic acid, $0.25 \mathrm{M} \mathrm{NaCl}$. All analyses for kinetic data were performed at least in triplicate.

The sensorgrams were analyzed by non-linear curve fitting using the BIAevaluation software, version 3.0.2, assuming single-site association and dissociation models (1:1 binding with drift base line). Optimal sections of each curve was selected, and the applicability of the chosen model was ascertained by evaluating the resulting fitted curves, using the residual plot function of the software (requiring a random point scattering for the fit to be accepted) as well as calculation of $\chi^{2}$ (requiring a $\chi^{2}$ value below 10 in both the association and dissociation phase for acceptance). Calculated values for the association rate constant $\left(\mathrm{k}_{\mathbf{a}}\right)$ and the dissociation constant $\left(k_{d}\right)$ were used for deriving the equilibrium dissociation constant $\left(K_{\mathrm{d}}=k_{\mathrm{d}} / \mathrm{K}_{\mathrm{a}}\right)$.

\section{Endothelial cell proliferation assay}

BCE proliferation assay was performed as previously described (O'Reilly et al., 1994). Cells were washed twice with PBS and trypsinized briefly with $0.05 \%$ trypsin solution. Cells were suspended in DMEM, 10\% FBS, $1 \%$ antibiotics and cell number was counted using a hemocytometer. 12,500 cells/well were plated into gelatinized 24-well culture plates and were incubated $\left(37^{\circ} \mathrm{C}\right.$ in $\left.10 \% \mathrm{CO}_{2}\right)$ for $24 \mathrm{~h}$. The media was replaced with $0.25 \mathrm{ml}$ of DMEM, 5\% FBS, $1 \%$ antibiotics and the test sample applied. After $30 \mathrm{~min}$ of incubation, $0.25 \mathrm{ml}$ of DMEM, 5\% FBS, $1 \%$ antibiotics, $2 \mathrm{ng} / \mathrm{ml}$ bFGF was added to each well. After 72 $h$, cells were dispersed in trypsin, and counted by a trypan blue exclusion method.

\section{Endothelial cell migration assay}

To evaluate migration, a modified Boyden chamber based assay was performed (Yamaguchi et al., 1999). Transwell polycarbonate membrane with $8 \mathrm{~mm}$ pore size (Costar) was coated with $0.1 \%$ gelatin. After HUVE cells were trypsinized and suspended in M199 medium $\left(4 \times 10^{5} \mathrm{cells} / \mathrm{ml}\right), 100 \mu \mathrm{l}$ was added to each well in the upper chamber. The filter was placed over a bottom chamber containing $2 \mathrm{ng} / \mathrm{ml}$ VEGF $_{165}$ in $0.1 \%$ BSA in M199 medium. For testing the inhibitory activity of recombinant proteins, HUVE cells were pre-incubated with the proteins in M199 medium in the cell culture incubator for $30 \mathrm{~min}$ before being added to the upper chamber. The assembled chamber was incubated for $5 \mathrm{~h}$ at $37^{\circ} \mathrm{C}$ with $5 \% \mathrm{CO}_{2}$ to allow cells to migrate through the gelatin-coated polycarbonate filter. The filter membrane was removed from the chamber, fixed with methanol, and stained with hematoxylin Gill No. 2 (Sigma) and eosin. Nonmigrated cells on the upper surface of the filter were removed by scraping with a cotton swab. The total number of migrated cells with nuclei per well was counted using digital photographic system.

\section{Chorioallantoic membrane (CAM) assay}

To determine anti-angiogenic activity in vivo, CAM assay was performed as previously described (Kim et al., 2003b). Fertilized eggs (Pulmuone, Korea) were incubated at $37^{\circ} \mathrm{C}$, and $70 \%$ relative humidity. At day 2 , a portion of albumin was removed and a window was made on day 3 . At day 4.5 of incubation, test samples loaded on a thermanox cover slip (Nunc) of quarter size were applied on the CAM of individual embryos. After another 2 days' incubation, Intralipose ${ }^{R}$ (KGCC, Korea) was injected into the CAM for observation of inhibition zone of angiogenesis.

\section{Results}

\section{Production and purification of U-ATF}

The recombinant plasmids constructed for the bacterial expression UK1 and U-ATF contain 6 histidine residues at carboxyl terminal end (Figure 1A). U-ATF was designed to span from Ser(1) to $\operatorname{Lys}(135)$, not including 'connecting peptide' (aa 136-158). The expressed protein exists in inclusion bodies as insoluble form. This protein was solublized, purified, and refolded in vitro, followed by final purification by size exclusion chromatography to homogeneity. The yield of purified protein is about $20 \%$ of the isolated inclusion bodies. The purified U-ATF migrated on SDSPAGE as a single band at $18 \mathrm{kDa}$ under reducing condition (Figure 1B). Under non-reducing condition, they migrated a little bit faster, corresponding well with the molecular weight expected. The calculated mass for U-ATF is 16,464 Da. 
A

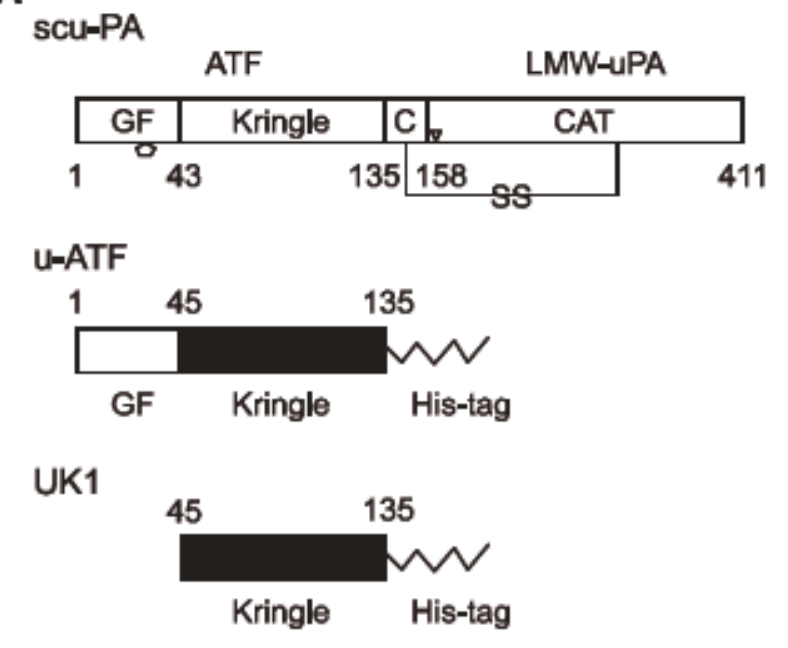

B

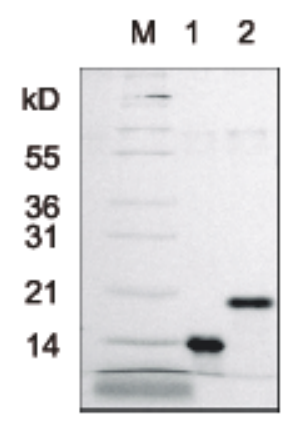

Figure 1. (A) Schematic structure of scu-PA and the recombinant constructs. The recombinant proteins used in his work contain His-tag at the carboxyl-term inus. GF, growth factor-like domain; C, connecting pepide; CAT, catalyfic domain; ATF, amino-termianl fragment; LMWUPA, low molecular weightuPA; pentagone, fucose at Thr (18); reverse triangle, cleavage sile by plasmin (Lys158-Ie159). (B) SDSPAGE analysis of purified recombinant proteins. Approximately $2 \mu g$ of each protein was run on $12 \%$ Tris-glycine-SDS gel under reducing condifion and sained with Coomassie blue. Lane 1, recombinant kringle domain of UPA (UK1); lane 2, recombinant ATF of UPA (U-ATF).

\section{Analysis of the interaction of UK1, U-ATF,} and scu-PA with UPAR by Biacore

ATF domain of UPA has been known to act as an antagonist for uPA receptor (Lu et al., 1996; Li et al., 1998). The interaction of these molecules with UPAR by Biacore assay was carried out in order to verify how refolded proteins, U-ATF and UK1 interact to UPAR with a measurable affinity. Recombinant human UPAR was immobilized directly to a carboxylated dextran matrix chip through amine group on UPAR, and purified UK1, U-ATF, or scu-PA was injected over the UPAR surface. Representative sensorgrams are shown Figure 2A. scu-PA and U-ATF were observed to bind to UPAR with specific affinity as expected. By contrast, UK1 did not show any binding under the identi-
Table 1. Kinefic constants measured by real-time interaction analysis Kinetic constants were determined using the Blacore system as described under "Experimental Procedures". ND, no specific binding delected.

\begin{tabular}{lccc}
\hline Protein samples & $\begin{array}{c}k_{\mathrm{a}} \times 10^{-4} \\
\left(\mathrm{~W}^{-1} \cdot \mathrm{s}^{-1}\right)^{\mathrm{a}}\end{array}$ & $\begin{array}{c}k_{\mathrm{d}} \times 10^{3} \\
\left(\mathrm{~s}^{-3}\right)^{\mathrm{a}}\end{array}$ & $\begin{array}{c}K_{\mathrm{d}} \\
\left(\mathrm{nM}^{\mathrm{b}}\right.\end{array}$ \\
\hline scu-PA & $166 \pm 20$ & $3.05 \pm 0.39$ & $1.84 \pm 0.00$ \\
U-ATF & $2.95 \pm 0.28$ & $3.56 \pm 0.14$ & $122 \pm 13$ \\
UK1 & ND & ND & ND \\
\hline
\end{tabular}

"Rale constants are expressed as the average value found for the three accepted fits in each case the standard deviation of these delermination. "The equilibrium dissociafon constant, $K_{d}$ was calculated as the ratio of the rate constants, $k_{0} / k_{2}$.

cal condition over a concentration range of $15.6 \mathrm{nM}$ to $500 \mathrm{nM}$, suggesting that kringle domain alone is not able to associate with UPAR (Kim et al., 2003b) (Figure 2B).

The kinetic parameters analyzed in another three sets of sensorgrams are summarized in Table I. u-ATF bound to uPAR with high affinity $\left(K_{d}=122 \pm 13\right.$ $\mathrm{nM})$ in a dose-dependent manner. The affinity of u-ATF, which has the $K_{\triangleleft}$ value about 66 fold higher than that of the whole molecule, scu-PA, was mainly from the result of a decrease in $k_{\mathrm{g}}$. In the previous report, ATF exhibits about a 10-50 fold higher ED50 in SaOS-2 and U-937 cells than does DFP-uPA in the competitive binding of ${ }^{125}$ /-ATF (Rabbani et al., 1992). It might suggest that uPA has an additional binding site(s) or modulating domain(s) for UPA/uPAR interaction. These results also indicate U-ATF was properly refolded without significant change in binding affinity for UPAR. In case of krinige module, bacteria-derived, refolded UK1 and yeast-derived, soluble form both also have proven to elicit almost identical anti-proliferative acivities on endothelial cells in the previous study (Kim et al., 2003a). CD spectra measured for these two proteins also showed almost identical pattern (data not shown).

\section{Effect of U-ATF on endothelial cell proliferation}

Purified U-ATF was compared with UK1 for their inhibitory activities on BCE cell growth stimulated by bFGF $(1 \mathrm{ng} / \mathrm{ml})$. While UK1 exerted a potent growth inhibitory effect on bFGF-stimulated BCE cells in a dose-dependent manner (Figure $3, E_{50}$ of about 80 $\mathrm{nM})$, the inhibitory potency of U-ATF was markedly lower than that of UK1, and its $\mathrm{ED}_{50}$ was beyond a concentration range measured $\left(E D_{50}>320 \mathrm{nM}\right)$. uATF displayed a tendency of dose-dependent inhibition, compared to scu-PA which did not affect BCE cell growth at all at a concentration up to $320 \mathrm{nM}$ in the previous study (Kim et al, 2003b). 

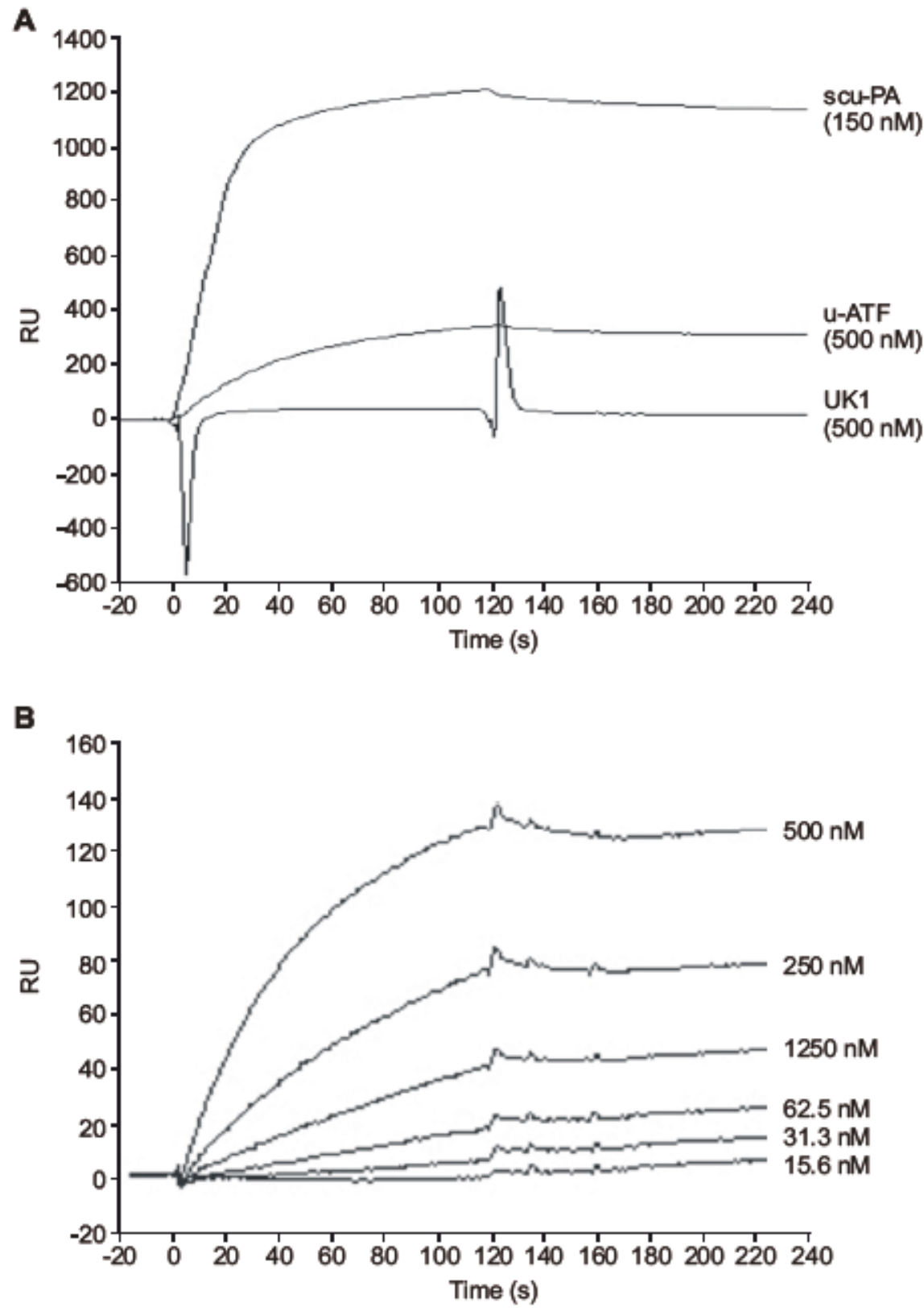

Figure 2. Real-time interaction analysis of binding $b$ immoblized recombinant UPA receptor. Ligand binding curves obtained by aubmated measurements of surface plasmon resonance (BIACORE technology). A carboxymethyl-type sensor chip was coupled covalently with uPAR as described under "Malerials and Methods". Immobilization of UPAR was performed in fow cell 2 while flow cell 1 was immobilized with bovine serum albumin. Samples of scu-PA (A), U-ATF (A, $B$ ), and UK-1 (A) were subjected to realtime interacion analysis with the coupled sensor chips, using a Biacore 2000 instrument. Different level of immobilization was applied; $(A)$ : for general analysis $\left(R_{\text {mat }}\right.$ $=5,100)$; $(B)$ : for kinetics $\left(R_{n}=780\right)$. The samples were diluted in running buffer for serial dilution. Ligand binding was measured at $20^{\circ} \mathrm{C}$ with passage of the samples through boh fow cells. The BAevaluaton software was used for the subtraction of bulk effects (towcell 1) and a blind curve obbined with buffer alone to compensate for drift.

\section{Inhibition of VEGF-induced endothelial cell migration by UK1 and U-ATF}

The migration response of the endothelial cells is more sensitive to VEGF than bFGF (Yoshida et al., 1996), VEGF-induced migration was employed to compare their activitities between U-ATF and UK1. VEGF (2 $\mathrm{ng} / \mathrm{ml})$ was used in the low chamber to stimulate the migration of HUVE cell subcultured to passage P3-P4. As shown in Figure 4, purified UK1 and U-ATF also displayed dose-dependent inhibition in a concentration range of $0.01 \mu \mathrm{g} / \mathrm{ml}$ to $10 \mu \mathrm{g} / \mathrm{ml}$, with $I_{50}$ of $-1 \mathrm{nM}$, and $600 \mathrm{nM}$, respectively. UK1 was about 600 fold more potent than U-ATF. Scu-PA itself did not inhibit or potentiate the VEGF-induced endothelial cell migration over a concentration range of $0.01 \mu \mathrm{g} / \mathrm{ml}$ to $10 \mu \mathrm{g} / \mathrm{ml}$.

\section{Anti-angiogenic activity of UK1 and U-ATF in the chick embryo}

To compare the ability of UK1 and U-ATF to inhibit in vivo angiogenesis, we used the chick chorioallantoic membrane assay. Purified UK1, and U-ATF 


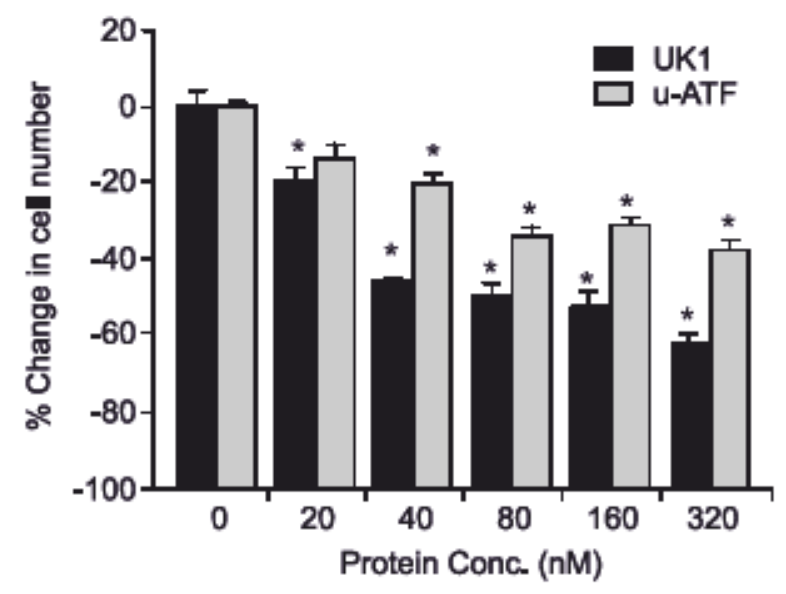

Figure 3. hhibition of endothleial cell proliferafon by UK1 and U-ATF. Anti-endothelial cell proliferative acfivites were assayed on BCE cell in the presence of $1 \mathrm{ng} / \mathrm{ml}$ bFGF for $72 \mathrm{~h}$. Values represent the mean of three determinations (S.E.) as percentages of inhibifon. ${ }^{*}, P<$ 0.01 .

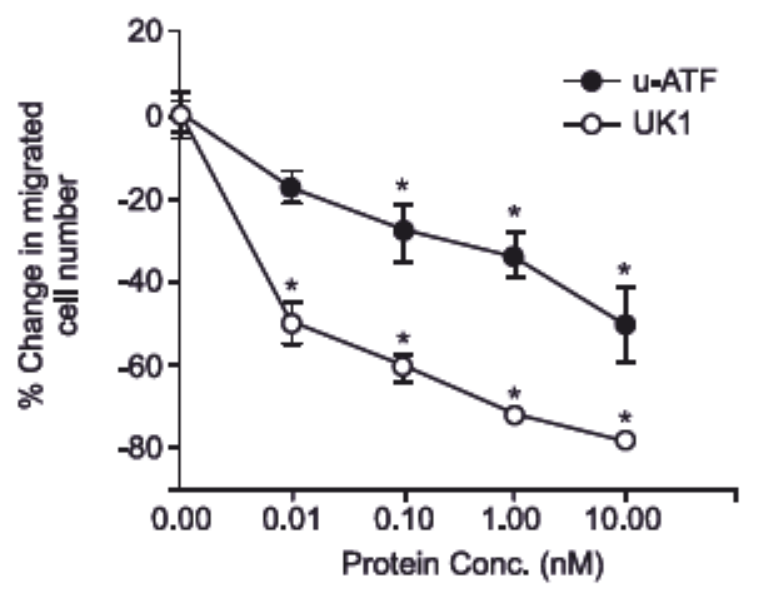

Figure 4. Inhibifion of VEGF-induced endothelial cell migrafon. Anti-migrabry activities of UK1 and U-ATF were examined at several doses in a Boyden chamber-based assay. HUVE cells were preincubated with test sample at each concentration for $30 \mathrm{~min}$ and VEGF (2 $\mathrm{ng} / \mathrm{ml})$ was used as a chemoattractant to elicit the migration of cells. Values, given as percentage of inhibition, represent the mean of three determinations (S.E.). ${ }^{*}, P<0.05$.

was found to inhibit in vivo angiogenesis at the different levels (Figure 5). At doses of $20 \mu \mathrm{g} / \mathrm{embryo}$, UK1 showed the potent inhibitory activity (57\% inhibition), whereas U-ATF showed the marginal inhibitory activity by showing $38 \%$ inhibition. Furthermore, the inhibition zone induced by high dose of u-ATF was not so distinct as that of UK1 and its dose-dependent inhibition could not be detected in this assay method. No toxicity was observed in embryos tested.

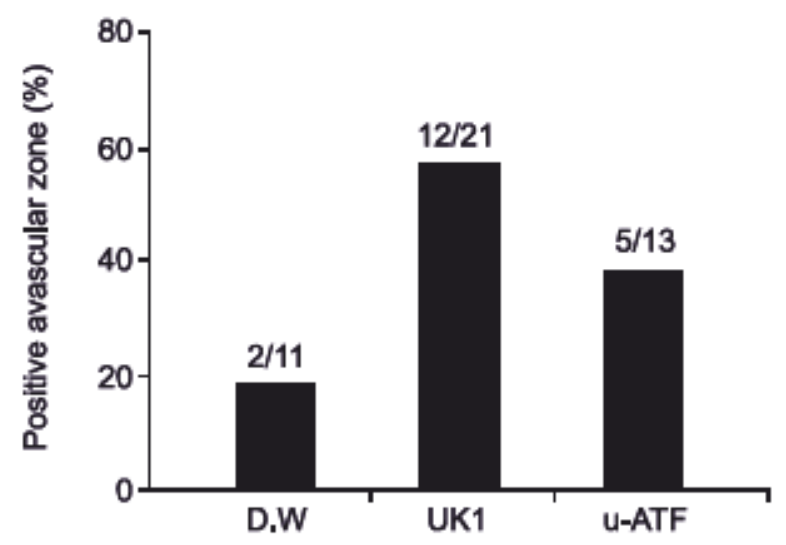

Figure 5. Comparison of in vivo anti-angiogenic acfivifes of U-ATF and UK1 in the chick CAM. Discs containing $20 \mu \mathrm{g}$ of each protein were applied to the CAMs of 4.5-day-old chick embryos. After $48 \mathrm{~h}$, the avascular zone ( $\geq 5 \mathrm{~mm}$ in diameter) of each CAM was examined. Ihibition (\%) of trealed samples is presented as the number of CAMs with avascular zones over the blal number of CAMs (indicated above each column).

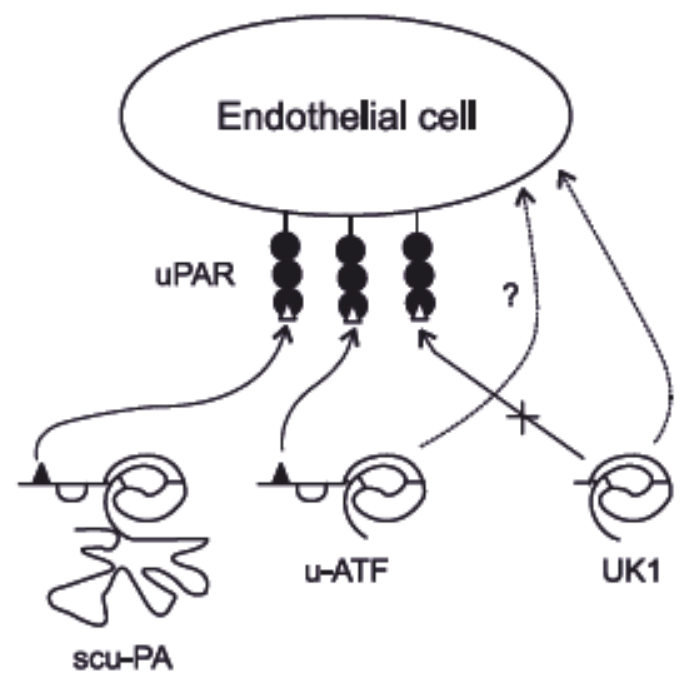

Figure 6. The proposed mechanisms of differential anti-angiogenic acitivity of U-ATF and UK1. The closed triangle represents growth factor-ike domain, which interacts with U-PA receplor. U-ATF interacts mainly with U-PAR b block uPA binding, alhough its kringle domain might interact with endothelial cells via a different mechanism to elicit anf-angiogenic function originated from its kringle structure. UK1 has no binding sile for UPAR. The most anti-angiogenic function of UK1 seems io come fom different interactons with endo helial cells, rather han UPA/UPAR interaction.

\section{Discussion}

Blockade of cell surface localization of uPA was reported to halt both angiogenesis and tumor growth/or metastasis (Min et al., 1996; Evans et al., 1997; Ignar et al., 1998). Suppression of tumor growth and dissemination by adenovirus-mediated delivery of an uPA/ uPAR antagonist, the amino-terminal fragment was 
reported to most likely result mainly from an inhibition of angiogenesis (Li et al., 1998; Li et al., 1999; Le Gat et al., 2003). However, the molecular basis of tumor growth and angiogenesis inhibition by uPA antagonists remains to be clarified. UPA has one kringle domain, which shares some homology with those of angiostatin kringles but distinct for being incapable of binding lysine residue. Recent our study demonstrated the kringle domain of UPA, UK1 is an anti-angiogenic molecule (Kim et al., 2003b). In the present study, we examined anti-angiogenic acitivites of UK1 and u-ATF in the identical assay systems. Importantly, our data demonstrated the kringle domain alone is sufficient for potent anti-angiogenic activity in vitro and in vivo. However, it could not be excluded that ATF can function more effectively in tumor models, considering that ATF domain has a potential cleavage site, Lys $^{46}$ - Ser ${ }^{47}$ for protease to produce UK1 (Bachman, 1994) and that UPA/UPAR interaction might play more important roles in tumor angiogenesis and metastasis.

Additional 45 amino acid-growth factor-like domain in U-ATF seems to divert anti-angiogenic mechanism of kringle domain. Based on the significantly different levels in inhibition of endothelial cell acitivity, u-ATF and UK1 may undergo different mechanisms for eliciting their antiangiogenic activities. In case of angiostatin, which has been studied for 10 years, its cellular and molecular action mechanism is still unclear. Our group reported that UK1 internalize specifically in endothelial cells and it also elicited a transient increase $\mathrm{Ca}^{2+}$ flux of more than 2-fold (Kim et al., 2003b). In inhibition of endothelial cell proliferation and migration, UK1 did not show any selectivity on angiogenic factors. The action mechanism of UK1 remains to be elucidated more precisely at the molecular level. In contrast to UK1, U-ATF binds to UPAR with high affinity, but is not able to elicit potent inhibitory activity on endothelial cell proliferation and migration. Since uPAR receptor exists in tumor cells besides endothelial cells, u-ATF seems to act in a non-selective manner, unlike UK1.

One possible explanation for the action mechanism of the differential anti-endothelial cell activities of UK1 and u-ATF can be suggested as shown in Figure 5 . The kringle domain alone acts on certain endothelial cell receptor(s) to elicit its potent anti-angiogenic activity, which might be via a mechanism similar to that for angiostatin kringles. By contrast, ATF domain mainly acts as a uPAR antagonist by binding to UPAR, although a minor portion of ATF may bind to the receptor for the kringle domain to elicit endothelial antiproliferative activity.

uPA plays important roles not only in angiogenesis, but also in tumor metastasis. A recombinant adenovirus encoding the non-catalytic ATF of mouse uPA prevents lung carcinoma metastasis (Li et al., 1998) and protects mice in a liver metastasis model of human colon carcinoma (Li et al., 1999). In regard to metastasis, U-ATF can be more effective than UK1. However, a kringle-based inhibitor, angiostatin also suppresses tumor growth and metastasis (O'Reilly et al., 1994). Thus, it will be interesting to examine the efficacy of UK1 and U-ATF molecules in in vivo tumor model, in regard to angiogenesis, tumor growth, and metastasis.

\section{Acknowledgem ent}

We thank Jun-Yeoung Jeon for the technical support for BIACORE biosensor assay. This work was supported by a grant from the Korea Health $21 \mathrm{R} \& D$ Project, Ministry of Health \& Welfare (02-PJ1-PG10-208020007).

\section{References}

Andreasen PA, Kjoller L, Christensen L, Duffy MJ. The urokinase-type plasminogen activator system in cancer metastasis: a review. Int J Cancer 1997;72:1-22

Bachman F. Molecular aspects of plasminogen, plasminogen activator, and plasmin. (Bloom AL, Forbes CD, Thomas DP, Tuddenham EGD, eds) Haemostasis and Thrombosis 1994; 575-613

Crowley C, Cohen R, Lucas B, Liu G, Shuman M, Levinson A. Prevention of Metastasis by Inhibition of the Urokinase Receptor. Proc Natl Acad Sci USA 1993;90:5021-5

de Vries TJ, van Mujen, G.N.P, Ruiter DJ. The plasminogen activation system in tumour invasion and metastasis. Pathol Res Pract 1996;192:718-33

Estreicher A, Muhlhauser J, Carpentier JL, Orci L, Vassalli JD. The receptor for urokinase type plasminogen activator polarizes expression of the protease to the leading edge of migrating monocytes and promotes degradation of enzyme inhibitor complexes. J Cell Biol 1990;111:783-92

Evans CP, Elfman F, Parangi S, Conn M, Cunha G, Shuman MA. Inhibition of prostate cancer neovascularization and growth by urokinase-plasminogen activator receptor blockade. Cancer Res 1997;57:3594-9

Fibbi G, Caldini R, Chevanne M, Pucci M, Schiavone $N$, Morbidelli L, Parenti A, Granger HJ, Del Rosso M, Ziche M. Urokinase-dependent angiogenesis in vitro and diacylglycerol production are blocked by antisense oligonucleotides against the urokinase receptor. Lab Invest 1998;78:1109-19

Foekens JA, Look MP, Peters HA, van Putten WL, Portengen $\mathrm{H}, \mathrm{Klijn}$ JG. Urokinase-type plasminogen activator and its inhibitor PAl-1: predictors of poor response to tamoxifen therapy in recurrent breast cancer. $J$ Natl Cancer Inst $1995 ; 87: 751-6$

Ignar DM, Andrews JL, Witherspoon SM, Leray JD, Clay WC, Kilpatrick K, Onori J, Kost T, Emerson DL. Inhibition of establishment of primary and micrometastatic tumors by a urokinase plasminogen activator receptor antagonist. Clin 


\section{Exp Metastasis 1998;16:9-20}

Jaffe EA, Nachman RL, Becker CG, Minick R. Culture of human endothelial cells derived from umbilical veins. Identification by morphologic and immunologic criteria. J Clin Invest $1973 ; 52: 2745-56$

Kim HK, Hong YK, Park HE, Hong SH, Joe YA. Secretory production of recombinant urokinase kringle domain in Pichla pastoris. J Microbiol Biotechnol 2003;13:591-7

Kim KS, Hong YK, Joe YA, Lee Y, Shin JY, Park HE, Lee $\| \mathrm{H}$, Lee SY, Kang DK, Chang Sl, Chung SI. Anti-angiogenic activity of the recombinant kringle domain of urokinase and its specific entry into endothelial cells. J Biol Chem 2003b; 278:11449-56

Le Gat L, Gogat K, Bouquet C, Saint-Geniez M, Darland D, Van Den Berghe $L$, Marchant D, Provost A, Perricaudet $M$, Menasche $M$, Abitbol $M$. In vivo adenovirus-mediated delivery of a UPA/UPAR antagonist reduces retinal neovascularization in a mouse model of retinopathy. Gene Ther 2003;10:2098103

Lee TH, Rhim TY, Kim SS. Prothrombin kringle-2 domain has a growth inhibitory activity against basic fibroblast growth factor-stimulated capillary endothelial cells. J Biol Chem $1998 ; 273: 28805-12$

Li H, Lu H, Griscelli $F$, Opolon P, Sun LQ, Ragot $T$, Legrand $Y$, Belin D, Soria J, Soria C, Perricaudet M, Yeh P. Adenovirus-mediated delivery of a UPA/UPAR antagonist suppresses angiogenesis-dependent tumor growth and dissemination in mice. Gene Ther 1998;5:1105-13

Li $H$, Griscelli $F$, Lindenmeyer $F$, Opolon $P$, Sun $L Q$, Connault E, Soria J, Soria C, Perricaudet M, Yeh P, Lu H. Systemic delivery of antiangiogenic adenovirus AdmATF induces liver resistance to metastasis and prolongs survival of mice. Hum Gene Ther 1999;10:3045-53

Lu H, Mabilat C, Yeh $P$, Guitton JD, Li H, Pouchelet $M$, Shoevaert D, Legrand $Y$, Soria J, Soria C. Blockage of urokinase receptor reduces in vitro the motility and the deformability of endothelial cells. FEBS Lett 1996;380:21-4

Mandriota SJ, Seghezzi G, Vassalli JD, Ferrara N, Wasi S, Mazzieri R, Mignatti P, Pepper MS. Vascular endothelial growth factor increases urokinase receptor expression in vascular endothelial cells. J Biol Chem 1995;270:9709-16

Mignatt $P$, Mazzieri R, Rifkin D. Expression of the urokinase receptor in vascular endothelial cells is stimulated by basic fibroblast growth factor. J Cell Biol 1991;113:1193-201

Min HY, Doyle LV, Vitt CR, Zandonella CL, Stratton-Thomas JR, Shuman MA, Rosenberg S. Urokinase receptor antagonists inhibit angiogenesis and primary tumor growth in syngeneic mice. Cancer Res 1996;15:2428-33

Mohanam S, Chandrasekar N, Yanamandra N, Khawar S, Mirza F, Dinh DH, Olivero WC, Rao JS. Modulation of invasive properties of human glioblastoma cells stably expressing amino-terminal fragment of urokinase-type plasminogen activator. Oncogene 2002;21:7824-30
O'Reilly MS, Holmgren L, Shing $Y$, Chen C, Rosenthal RA, Moses M, Lane WS, Cao Y, Sage EH, Folkman J. Angiostatin: a novel angiogenesis inhibitor that mediates the suppression of metastases by a Lewis lung carcinoma. Cell $1994 ; 79: 315-28$

Park IK, Kim BJ, Goh YJ, Lyu MA, Park CG, Hwang ES, Kook YH. Co-expression of urokinase-type plasminogen activator and its receptor in human gastric-cancer cell lines correlates with their invasiveness and tumorigenicity. Int $\mathrm{J}$ Cancer 1997;71:867-73

Petersen LC, Lund LR, Nielsen LS, Dano K, Skriver L. One-chain urokinase-type plasminogen activator from human sarcoma cells is a proenzyme with little or no intrinsic activity. J Biol Chem 1988;263:11189-95

Rabbani SA, Mazar AP, Bernier SM, Haq M, Bollvar I, Henkin J, Goltzamn. Structural requirements for the growth factor activity of the amino-terminal domain of urokinase. $J$ Biol Chem 1992;267:14151-6

Reuning U, Magdolen V, Wilhelm O, Fischer K, Lutz V, Graeff $H$, Schmitt M. Multifunctional potential of the plasminogen activation system in tumor invasion and metastasis (review). Int J Oncol 1998;13:893-906

Saksela O, Moscatelli D, Rifkin DB. The opposing effects of basic fibroblast growth factor and transforming growth factor beta on the regulation of plasminogen activator activity in capillary endothelial cells. J Cell Biol 1987;105:957-63

Sappino AP, Busso N, Belin D, Vassalli JD. Increase of urokinase-type plasminogen activator gene expression in human lung and breast carcinomas. Cancer Res 1987;47: $4043-6$

Yamaguchi N, Anand-Apte B, Lee M, Sasaki T, Fukai N, Shapiro R, Que I, Lowik C, Timpl R, Olsen BR. Endostatin inhibits VEGF-induced endothelial cell migration and tumor growth independently of zinc binding. EMBO J 1999;18: 4414-23

Yamamoto $M$, Sawaya R, Mohanam S, Bindal AK, Bruner JM, Oka K, Rao VH, Tomonaga M, Nicolson GL, Rao JS. Expression and localization of urokinase-type plasminogen activator in human astrocytomas in vivo. Cancer Res 1994a; 54:3656-61

Yamamoto M, Sawaya R, Mohanam S, Rao VH, Bruner JM, Nicolson GL, Rao JS. Expression and localization of urokinase-type plasminogen activator receptor in human gliomas. Cancer Res 1994b;54:5016-20

Yasunaga C, Nakashima $Y$, Sueishi K. A role of fibrinolytic activity in angiogenesis. Quantitative assay using in vitro method. Lab Invest 1989;61:698-704

Yoshida A, Anand-Apte B, Zetter BR. Differential endothelial migration and proliferation to basic fibroblast growth factor and vascular endothelial growth factor. Growth Factors 1996; 13:57-64 